\title{
Population sizes, status and habitat associations of the restricted-range bird species of Sumba, Indonesia
}

\author{
MARTIN J. JONES, MARK D. LINSLEY and STUART J. MARSDEN
}

\section{Summary}

The island of Sumba was visited in 1989 and 1992 with the aim of collecting data on its avifauna. The endemic and other restricted-range bird species are very poorly known and, potentially, at great risk from extinction due to habitat change. Using standardized methods, habitat and bird census data were collected in eight forest areas. Analysis of the habitat data shows that most of the restricted-range species are forest-dependent. The exception is Turnix everetti (Sumba Buttonquail), which is found in open grassland. Discriminant Function Analysis was used to define habitat associations in a more precise and objective way. The species with the most specific requirements are Ptilinopus dohertyi (Red-naped Fruit-dove) and Zoothera dohertyi (Chestnut-backed Thrush), which are associated with primary forest at high altitudes, and Cacatua sulphurea (Sulphur-crested Cockatoo) and Rhyticeros everetti (Sumba Hornbill), which prefer evergreen primary or mature secondary forest at low altitudes. The results of the bird censuses were combined with data on habitat cover from satellite photographs to produce estimates of total population sizes. Among the rarest and most endangered species on Sumba are three which are represented by endemic subspecies: $C$. sulphurea (estimated population 3,200 birds), Eclectus roratus (Eclectus Parrot) (1,900), Tanygnathus megalorynchos (Great-billed Parrot) $(1,700)$. The rarest endemic species is $R$. everetti, with a population of approximately 6,500 . It is suggested that the census method used - point counts with distance estimates to bird contacts - is the best compromise for multi-species surveys in tropical forests.

\section{Introduction}

\section{Sumba}

Sumba $\left(10^{\circ} \mathrm{Oo}^{\prime} \mathrm{S} 120^{\circ} \mathrm{Oo}\right.$ 'E) is located in the Lesser Sunda chain in the western part of Nusa Tenggara province in south-eastern Indonesia. The island is $210 \mathrm{~km}$ long with a surface area of $c .12,000 \mathrm{~km}^{2}$, and the highest point is Gunung Wanggameti at $1,225 \mathrm{~m}$. The climate is seasonal with annual rainfall of between $500 \mathrm{~mm}$ (south coast) and 2,000 $\mathrm{mm}$ (inland hills).

Closed-canopy forest (mostly deciduous but with some evergreen) now covers less than $11 \%$ of the island (McKnight et al. in prep.) and is confined to relatively small and fragmented pockets. The area of forest has declined by over $60 \%$ since 1927 (McKnight et al. in prep.) and the main cause of forest loss is the clearing and repeated burning of vegetation to provide land for grazing and 
cultivation. Although there is removal of trees for local use, Sumba has no logging industry.

In many areas, as a result of the shifting cultivation and annual burning for cattle grazing, the original vegetation has been replaced by fire-resistant trees, shrubs and grasses. Where grazing and burning have been particularly intensive the grasslands have become degraded and soil erosion is evident.

\section{The bird fauna}

Sumba has been classified as one of Indonesia's 24 Endemic Bird Areas (ICBP 1992) and thus as a priority area for the conservation of global biodiversity.

Following White and Bruce (1986) and Andrew (1992), Sumba has seven endemic species: Turnix everetti (Sumba Buttonquail), Treron teysmanni (Sumba Green-pigeon), Ptilinopus dohertyi (Red-naped Fruit-dove), Ninox rudolfi (Sumba Boobook), Rhyticeros everetti (Sumba Hornbill), Ficedula harterti (Sumba Flycatcher) and Nectarinia buettikoferi (Apricot-breasted Sunbird). The endemic races of a further two species Muscicapa dauurica (Asian Brown Flycatcher) and Myzomela erythrocephala (Red-headed Myzomela) are accorded full species status by Sibley and Monroe (1990), who name them Muscicapa segregata and Myzomela dammermani respectively (the former names are retained here). A number of non-endemic species are also considered in this paper, either because they have restricted geographical ranges - Halcyon australasia (Cinnamon-banded Kingfisher), Coracina dohertyi (Sumba Cicadabird), Rhinomyias oscillans (Russet-backed Rhinomyias), Pitta elegans (Elegant Pitta), Zoothera dohertyi (Chestnut-backed Thrush) and Zosterops wallacei (Yellow-spectacled White-eye) or because they are endemic subspecies which are known to be rare on Sumba: Cacatua sulphurea (Sulphur-crested Cockatoo), Eclectus roratus (Eclectus Parrot) and Tanygnathus megalorynchos (Great-billed Parrot) (Jones and Banjaransari 1990).

\section{History of ornithological research on Sumba}

The first bird collections on Sumba were made by J. G. F. Riedel between 1878 and 1880 (Meyer 1882) and by H. F. C. ten Kate in 1891-1892 (Büttikofer 1892). Between them they recorded a total of 64 species, including, most notably, the endemic Ninox rudolfi (Sumba Boobook) (Meyer 1892). An account of William Doherty's 1896 visit to Sumba and his collection is given by Hartert (1896), while Hartert (1898) relates the findings of Alfred Everett and his hunters from their visit in 1896 . Further collections were made by K. W. Dammerman in 1925 (Dammerman 1926a, b, Rensch 1931) and by G. H. W. Stein in 1932 (Mayr 1944). The last major collecting expedition was led by E. R. Sutter in 1949 (Bühler and Sutter 1951, Sutter 1955). The latter publication deals with the bird specimens collected, while the former contains some useful general information about the locations visited.

The first conservation-based visit to Sumba was by a Food and Agriculture Organization/United Nations Development Project (FAO/UNDP) team in 1979 (FAO 1982). This group visited two forest patches and evaluated the conservation status of other forest areas on Sumba. 
Sumba's coastal habitats and also some of its forests were surveyed in 1990 by Zieren et al. (1990) and other observations were made in September 1991 by M. Riffel and D. Bekti (in litt.) and in December 1991 by D. A. Holmes (in litt.).

This paper is based on two visits to Sumba. The first was between 18 September and 2 October 1989 and the second between 27 July and 23 September 1992. In 1989 the research was carried out by a group of seven staff and students from the Manchester Metropolitan University (MMU) together with two staff from the Indonesian Directorate General of Forest Protection and Nature Conservation (PHPA). The group in 1992 consisted of eleven staff and 21 postgraduate and undergraduate students from MMU, other British Universities, Katholic Widayah and Nusa Cendana Universities (Timor), Universitas Nasional (Jakarta), PHPA and the BirdLife Indonesia Programme. Both expeditions were sponsored by the Indonesian Institute of Sciences (LIPI).

\section{Aims of the $M M U$ study}

Comparatively little was known about the status and general biology of any of Sumba's bird species. This is particularly significant for the endemic taxa, many of which may be dependent on the rapidly dwindling forests. The main aim of the study, therefore, was to identify which species are at risk and to provide information to support their conservation. Until recently there were no protected areas on Sumba, and so a further aim was to provide some of the biological data needed to designate such areas. A final aim was to evaluate some of the currently available, yet in the tropics little-researched, methods for estimating populations and establishing habitat preferences.

We attempted to collect data on all of Sumba's bird and butterfly species (see Jones et al. 1994) but in this paper we confine analysis to the endemic and other restricted-range bird species and subspecies (Table 1).

\section{Methods}

\section{Study areas and census routes}

This paper reports on the results of two visits to Sumba. On the first, in 1989, six weeks were spent in two forest areas which had previously been recommended for conservation by the regional governor or the FAO/UNDP project. In 1992 a further four of the recommended areas were visited plus two forests in the west of Sumba. The location of all the study sites is shown in Figure 1 and other details are given in Table 2.

In each of the areas visited, semi-permanent transect routes were set up. These routes often followed existing paths or stream beds, but occasionally we established new tracks. Every 250 paces (in forest) or 400 paces (in scrub/ grassland) along each route, coloured tape was used to denote a census station. If the route followed a well-defined path or stream bed, every other census station was placed 50 paces at right angles to the main route. It was hoped that this might control for some of the "edge effects" on bird distribution and habitat structure. Ideally all the census points should have been randomly chosen (Buckland et al. 1993). This was not done because of the time required to travel 
Table 1. List of restricted-range bird species of Sumba

\begin{tabular}{ll}
\hline Species & Status \\
\hline Turnix everetti Sumba Button-quail & $\mathrm{E}$ \\
Treron teysmannii Sumba Green-pigeon & $\mathrm{E}$ \\
Ptilonopus dohertyi Red-naped Fruit-dove & $\mathrm{E}$ \\
Cacatua sulphurea Sulphur-crested Cockatoo & $\mathrm{SS}$ \\
Eclectus roratus Eclectus Parrot & $\mathrm{SS}$ \\
Tanygnathus megalorynchos Great-billed Parrot & $\mathrm{SS}$ \\
Ninox rudolphi Sumba Boobook & $\mathrm{E}$ \\
Halcyon australasia Cinnamon-banded Kingfisher & $\mathrm{R}$ \\
Rhyticeros everetti Sumba Hornbill & $\mathrm{E}$ \\
Pitta elegans Elegant Pitta & $\mathrm{R}$ \\
Coracina dohertyi Sumba Cicadabird & $\mathrm{S} / \mathrm{F}$ \\
Zoothera dohertyi Chestnut-backed Thrush & $\mathrm{R}$ \\
Rhinomyias oscillans Russet-backed Rhinomyias & $\mathrm{S} / \mathrm{F}$ \\
Muscicapa dauurica Asian Brown Flycatcher & $\mathrm{E} ?$ \\
Ficedula harterti Sumba Flycatcher & $\mathrm{E}$ \\
Nectarinia buettikoferi Apricot-breasted Sunbird & $\mathrm{E}$ \\
Zosterops wallacei Yellow-spectacled White-eye & $\mathrm{R}$ \\
Myzomela erythrocephala Red-headed Myzomela & $\mathrm{E} ?$ \\
\hline
\end{tabular}

$E$, endemic species; SS, èndemic and threatened sub-species; R, retricted-range species (ICBP 1992); $\mathrm{S} / \mathrm{F}$, endemic to Sumba, Sumbawa and Flores; E?, considered to be endemic by Sibley and Monroe (1990) but not by White and Bruce (1986).

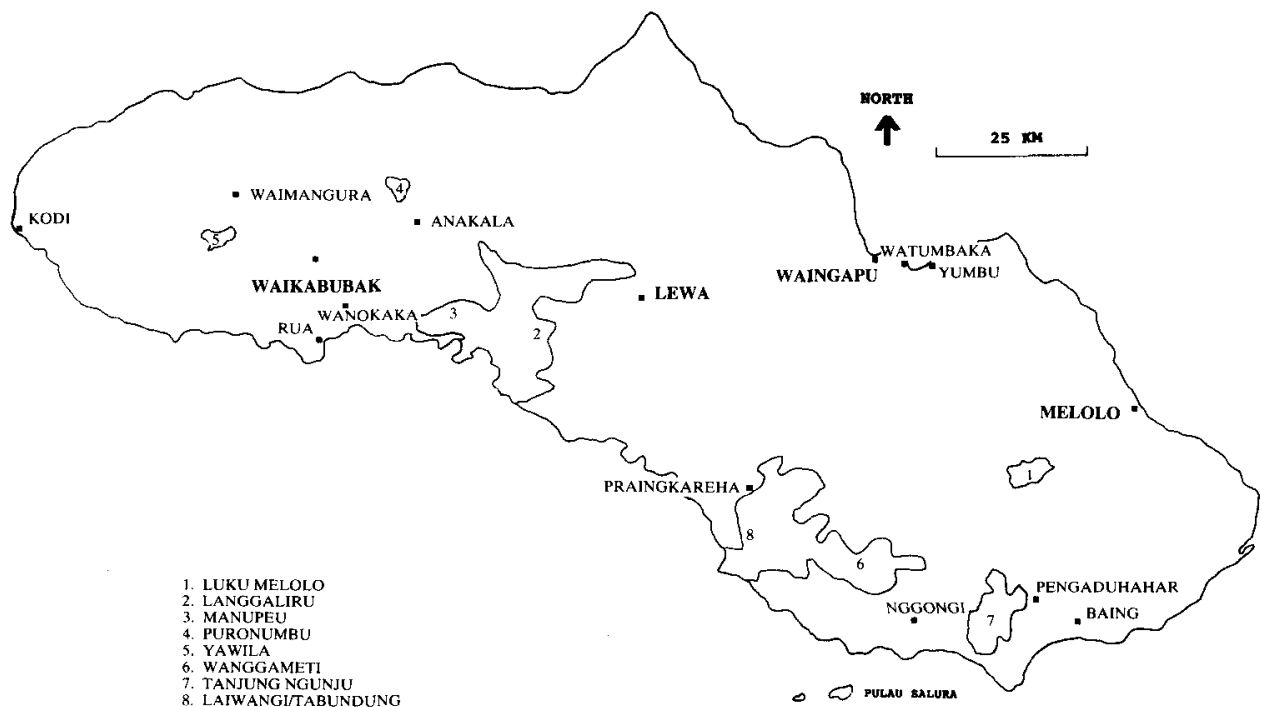

Figure 1 . Location of the eight study sites on Sumba, Indonesia.

between, and relocate, random points and, particularly, the safety problems associated with observers moving away from paths.

\section{Habitat recording}

Features of the habitat were recorded at all census stations, of which there were 556 in total. Habitat recording was concentrated within a circle of $30 \mathrm{~m}$ radius 
Table 2. Locations and dates of fieldwork

\begin{tabular}{|c|c|c|c|c|c|}
\hline \multirow[t]{2}{*}{ Site (local name) } & \multirow[t]{2}{*}{ Coordinates } & \multirow[t]{2}{*}{ Dates } & \multirow[t]{2}{*}{ Nearest village } & \multicolumn{2}{|c|}{ Number of stations } \\
\hline & & & & Forest & Forest edge \\
\hline $\begin{array}{l}\text { Luku Melolo/ } \\
\text { Laundung }\end{array}$ & $9^{\circ} 57^{\prime} \mathrm{S} 120^{\circ} 32^{\prime} \mathrm{E}$ & $23 / 7$ to $5 / 81992$ & Paberamanera & 120 & 43 \\
\hline Langgaliru (Nerip) & $9^{\circ} 46^{\prime} \mathrm{S} 119^{\circ} 32^{\prime} \mathrm{E}$ & $8 / 8$ to $20 / 81992$ & Umamanu & 118 & 40 \\
\hline $\begin{array}{l}\text { Manupeu } \\
\text { (Matayangu) }\end{array}$ & $9^{\circ} 42^{\prime} \mathrm{S} 119^{\circ} 32^{\prime} \mathrm{E}$ & $26 / 8$ to $31 / 81992$ & & 57 & 4 \\
\hline Puronumbu & $9^{\circ} 29^{\prime} \mathrm{S} 119^{\circ} 31^{\prime} \mathrm{E}$ & $4 / 9$ to $10 / 91992$ & & 55 & 21 \\
\hline Yawila & $9^{\circ} 35^{\prime} \mathrm{S} 119^{\circ} 15^{\prime} \mathrm{E}$ & $11 / 9$ to $15 / 91992$ & & 32 & 7 \\
\hline Gunung Wanggameti & $10^{\circ} \mathrm{O}^{\prime} \mathrm{S} 120^{\circ} 14^{\prime} \mathrm{E}$ & $18 / 9$ to $23 / 91992$ & Wanggameti & 50 & 9 \\
\hline Tanjung Ngunju & $10^{\circ} 13^{\prime} \mathrm{S} 120^{\circ} 26^{\prime} \mathrm{E}$ & $18 / 9$ to $2 / 101989$ & Pengaduhahar & 60 & 44 \\
\hline Laiwangi/Tabundung & $10^{\circ} 03^{\prime} \mathrm{S} 120^{\circ} 3^{\prime} \mathrm{E}$ & $8 / 10$ to $21 / 101989$ & Praingkareha & 70 & 24 \\
\hline
\end{tabular}

centred on the census station. Birds were recorded at much greater distances than this but it was impossible to get reliable vegetation data from a wider area.

At each station percentage cover of vegetation was estimated for ground level $(<1 \mathrm{~m})$, low level $(1-5 \mathrm{~m})$, mid-canopy $(>5-15 \mathrm{~m})$ and the canopy itself. The nearest 10 trees with a diameter at breast height $(\mathrm{DBH})$ of over $0.2 \mathrm{~m}$ were selected, their girth and distance to the central point measured, and their height estimated. Where possible the heights were checked with the aid of a clinometer. Each tree was also recorded as deciduous or evergreen and with or without fruit.

An indication of the past history of each area was provided by recording tree "architecture" using a method adapted from work by Torquebiau (1986). For each tree we recorded whether the point of inversion (site of first major branch) was above or below half the height of the tree. We also recorded the presence of large scars on the trunk below the point of inversion and the direction of growth of branches above the inversion. The rationale behind this recording scheme is that when trees grow up underneath the canopy, they do not normally branch until they reach the higher light levels at, or near, the canopy. In this case the point of inversion is well above half the tree height. If trees grow in an area which has been cleared, they branch lower down - usually below half the height of the tree. When a tree grows in a gap created by tree-fall or in a secondary forest which is maturing, there may be a secondary reaction to the closure of the forest canopy. This reaction (termed regeneration in this paper) might take the form of a shedding of the lower branches and a vertical growth of the crown to reach the canopy. In this case the main inversion may be above half the height but there will be major scars below. Alternatively, the lower branches might not be shed but grow vertically and thus push the crown into the closing canopy.

Other information collected at the stations included an estimate of the average gradient within $30 \mathrm{~m}$ of the census point, the distance to any water source, the approximate width of any path, and the altitude. The latter was measured by an altimeter which was calibrated at known altitudes.

The habitat data were manipulated in various ways before analysis. Tree density was expressed as the density of trees within the $30 \mathrm{~m}$ radius circle at each station. Biomass was roughly calculated as cubic metres of tree trunk 
(height $\times$ basal area) per hectare of area. The measurements of the 10 trees were averaged to give one mean value of tree height and tree girth for each station. The numbers of deciduous, fruiting and dead trees were expressed as a percentage of the 10 at each station. Using the architecture data, the numbers of trees branching above half their height, below half-height and regenerating (see above) were also expressed as a percentage of the 10 trees at each station. All percentage values were "normalized" by converting to their arcsines before further analysis.

Some of the forest edge stations did not have to trees of DBH greater than $0.2 \mathrm{~m}$ within $30 \mathrm{~m}$. Calculating percentages is obviously a problem with a small number of trees, so stations were excluded (but only for the Discriminant Function Analysis; see below) if there were less than six trees within $30 \mathrm{~m}$. This only applied to a total of four stations.

The main tool used to analyse the habitat associations of the restricted-range species was Discriminant Function Analysis (DFA). This method compares the habitat characteristics (the measured or estimated habitat variables) between stations where a bird species is present (positives) and those where it is absent (negatives). DFA establishes if there is a significant difference between the habitats at positive and negative stations and identifies which variables are involved in that discrimination, i.e. which aspects of the habitat are associated with the presence or absence of a bird species. The original habitat variables are ranked according to their discriminating power and the variables with the highest ranks can then be used to construct a profile of the habitat where each species is found.

\section{Bird censusing}

At each of the census stations the distances to all bird contacts were estimated. If a bird was seen to take flight the distance to the take-off point was estimated. Any flying birds that were not seen to take off were excluded from the estimates of population densities, for the reasons outlined by Buckland et al. (1993). For each contact, as well as distance, an estimate of height was made according to the following categories: ground (below $1 \mathrm{~m}$ ); low $(1-5 \mathrm{~m})$; medium $(5-15 \mathrm{~m})$ and high (over $15 \mathrm{~m}$ ). Contacts were only assigned to a category if their positions were obvious and they were not flying.

Each bird recorded was classified as a sighting, a call, or a sighting and call, although for the analyses presented here all were treated equivalently as "contacts". When approaching a station, if any birds were disturbed, we presumed that these would have been recorded from the station; we thus recorded the distance from the site of disturbance to the census station. In order to reduce the effect of disturbance on the censusing, the actual recording period commenced at least two minutes after the observers arrived at each station. Two observers then spent 10 minutes recording and producing a joint list of bird contacts. Each 10-minute session was divided into two-minute segments to allow an investigation into the effects of variation in recording periods. This aspect is not analysed here.

Most transects were walked twice, the second time with at least one different observer. At Luku Melolo, Langgaliru and Manupeu, as part of a study of the 
reliability and repeatability of the census methods, a small number of stations (28) were sampled eight times. These aspects are not examined in this paper but data from the repeated stations were included for analysis. The repeats were treated as multiple samples of the same station because they would not produce independent estimates of the bird populations in each area.

All censuses, whether initial or repeated, were carried out between o6hoo and 10hoo; this was because, from initial observations, it was obvious that bird activity declined considerably towards midday.

Although the point count data were collected in both the 1989 and 1992 field seasons, only the 1992 data are used to calculate total population estimates. Four fieldworkers were responsible for collecting the bird census data; three of these (M.J.J., M.D.L., S.J.M.) were involved in both years (and in other fieldwork on the islands of Seram, Obi and Buru) so that by 1992 all the species could be confidently identified from sightings and calls and the team had considerable experience in distance estimations. This experience was reinforced at the beginning of the 1992 field period mostly by estimating and then measuring distances to known points (usually the trees used for the habitat surveys).

The bird census data were analysed with the "Distance" program (Laake et al. 1993) which uses the estimates of distance to bird contacts to calculate population densities.

\section{Results}

\section{Habitat associations}

Turnix everetti was not recorded at any of the census stations, and Ninox rudolfi and Muscicapa dauurica were only rarely recorded. For these three species, some comments on their habitat associations are made in the species account section, but they do not feature in the analyses of habitat associations below.

A first indication of gross habitat preference is shown in Table 3 where the occurrence of the bird species is expressed as mean number of individuals per station in forest or forest-edge habitats. Forest stations were defined as those with at least $10 \%$ canopy cover and which were adjacent to at least one other "forest" station. The forest edge stations were in areas adjacent to the main forest blocks and where forest was mixed with scrub and grassland. A small number of stations which were in areas of pure grassland and cultivation were excluded from the analysis.

It is clear from Table 3 that the majority of the species are heavily dependent on forest. Only Nectarinia buettikoferi was more frequent in forest edge areas although Pitta elegans and Zosterops wallacei showed similar densities in forest and forest-edge areas.

Table 4 shows the results of another simple aspect of habitat preference, namely the height at which birds were recorded. The numbers at each height and that number as a percentage of total observations are shown for each species. Treron teysmanni, Cacatua sulphurea, Eclectus roratus, Tanygnathus megalorynchos and Rhyticeros everetti are obviously canopy species, as approximately $90 \%$ or more of contacts were in that height category. Ptilinopus dohertyi, Coracina dohertyi and Myzomela erythrocephala appear to use mid-levels $(5-15 \mathrm{~m})$ rather 
Table 3. Mean numbers of each bird species, per station, in forest and forest edge

\begin{tabular}{lcc}
\hline & Forest $n=432$ & Forest edge $n=124$ \\
\hline Treron teysmannii & $\mathbf{0 . 1 1}$ & 0.06 \\
Ptilonopus dohertyi & $\mathbf{0 . 2 0}$ & 0.03 \\
Cacatua sulphurea & $\mathbf{0 . 1 5}$ & 0.01 \\
Eclectus roratus & $\mathbf{0 . 2 6}$ & 0.13 \\
Tanygnathus megalorynchos & $\mathbf{0 . 1 3}$ & 0.06 \\
Halcyon australasia & $\mathbf{0 . 0 9}$ & 0.01 \\
Rhyticeros everetti & $\mathbf{0 . 2 1}$ & 0.03 \\
Pitta elegans & $\mathbf{0 . 1 3}$ & 0.11 \\
Coracina dohertyi & $\mathbf{0 . 0 8}$ & 0.02 \\
Zoothera dohertyi & $\mathbf{0 . 2 0}$ & 0.02 \\
Rhinomyias oscillans & $\mathbf{0 . 0 6}$ & 0.01 \\
Ficedula harterti & $\mathbf{0 . 1 1}$ & \\
Nectarinia buettikoferi & $\mathbf{1 . 2 5}$ & $\mathbf{1 . 4 4}$ \\
Zosterops wallacei & $\mathbf{0 . 7 8}$ & 0.73 \\
Myzomela erythrocephala & $\mathbf{0 . 2 0}$ & 0.01 \\
\hline
\end{tabular}

$n$, number of stations in each habitat.

The higher mean density for each species is shown in bold type.

Table 4. Heights of contacts with each bird species

\begin{tabular}{|c|c|c|c|c|c|c|c|c|}
\hline & \multicolumn{2}{|c|}{ Ground } & \multicolumn{2}{|c|}{ Low level } & \multicolumn{2}{|c|}{ Mid-level } & \multicolumn{2}{|c|}{ Canopy } \\
\hline & $n$ & $\%$ & $n$ & $\%$ & $n$ & $\%$ & $n$ & $\%$ \\
\hline Treron teysmanii & & & & & 3 & 10.7 & 39 & $89 \cdot 3$ \\
\hline Ptilinopus dohertyi & & & & & 27 & 31.0 & 59 & 69.0 \\
\hline Cacatua sulphurea & & & & & 4 & 11.8 & 30 & 88.2 \\
\hline Eclectus roratus & & & $\mathbf{1}$ & 2.3 & 3 & 7.0 & 39 & 90.7 \\
\hline Tanygnathus megalorynchos & & & & & 1 & 4.0 & 24 & 96.0 \\
\hline Halcyon australasia & & & 6 & 16.7 & 18 & 50.0 & 12 & $33 \cdot 3$ \\
\hline Rhyticeros everetti & & & & & 3 & 4.5 & 63 & $95 \cdot 5$ \\
\hline Pitta elegans & 47 & 78.0 & 13 & 20.0 & 5 & $7 \cdot 7$ & & \\
\hline Coracina dohertyi & & & & & 14 & 41.2 & 20 & 58.8 \\
\hline Zoothera dohertyi & & & 15 & 17.6 & 67 & $7^{8.8}$ & 3 & $3 \cdot 5$ \\
\hline Rhinomyias oscillans & 3 & 12.5 & 5 & 20.8 & 16 & 66.7 & & \\
\hline Ficedula harterti & & & 26 & 63.4 & 10 & $24 \cdot 4$ & 5 & 12.2 \\
\hline Nectarinia buettikoferi & & & 70 & 10.7 & 257 & 39.2 & 328 & 50.1 \\
\hline Zosterops wallacei & & & 5 & 1.4 & 182 & 50.7 & 172 & $47 \cdot 9$ \\
\hline Myzomela erythrocephala & & & & & 19 & 22.6 & 65 & $77 \cdot 4$ \\
\hline
\end{tabular}

$n$, number of birds recorded at each height; \%, percentage of the total seen recorded at each height.

more, although they were still more often recorded in the canopy. Halcyon australasia, $N$. buettikoferi and $Z$. wallacei are more catholic, using low, mid- and canopy levels. Considering the two flycatcher species, Rhinomyias oscillans was most frequent at mid-level but was recorded down to ground level, whilst Ficedula harterti was commonest at low level, although not seen on the ground during censusing (but it was occasionally at other times) and also recorded in the canopy. Zoothera dohertyi and $P$. elegans show a fairly narrow preference for midand ground levels respectively.

A more detailed, and hopefully more objective, indication of habitat associations was provided by a Discriminant Function Analysis (see "Habitat record- 


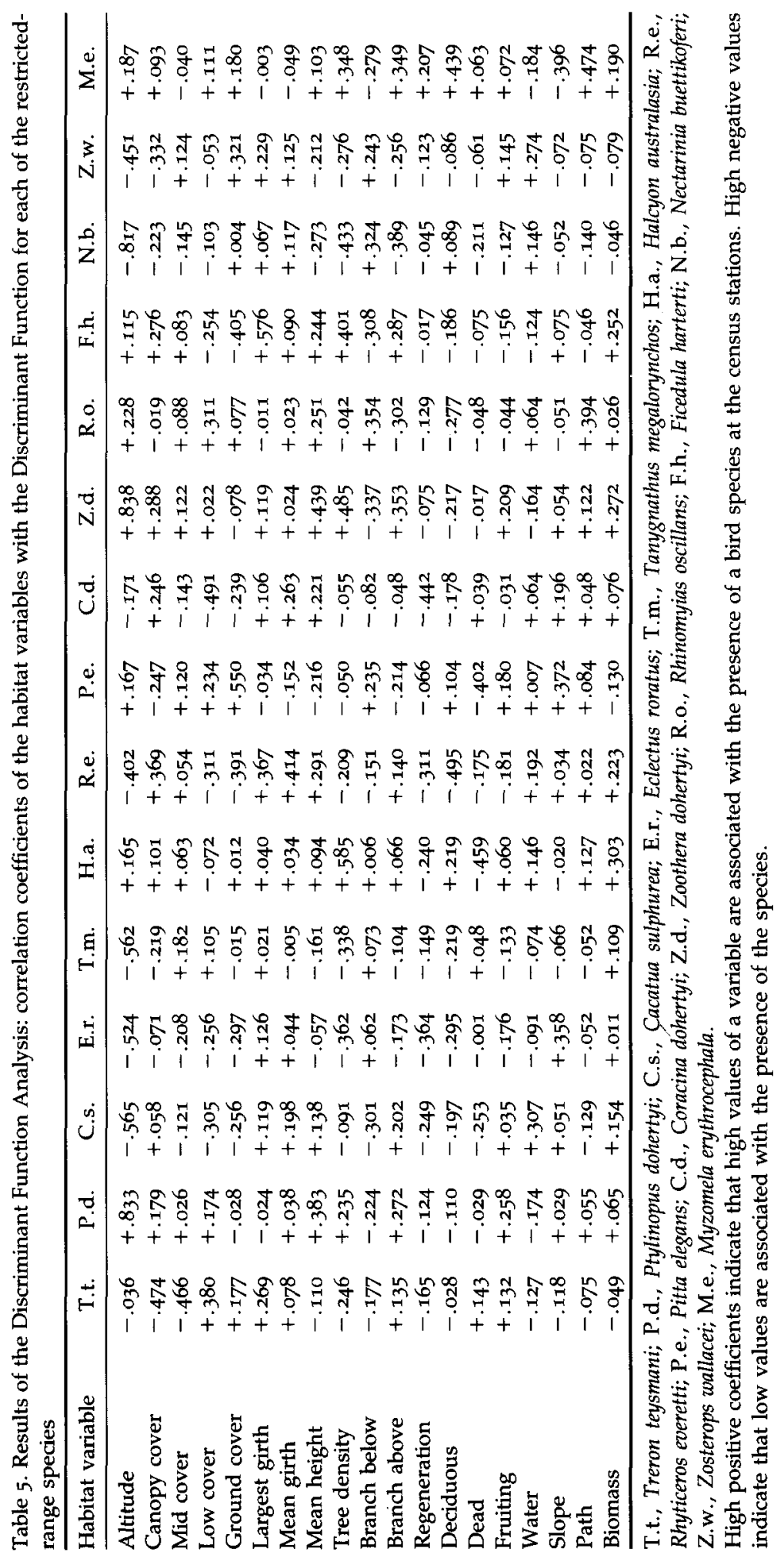


Table 6. Discriminant function analysis of habitat associations

\begin{tabular}{lll}
\hline & Discriminating variables & Interpretation \\
\hline $\begin{array}{l}\text { Treron teysmanii } \\
\chi^{2}=26.71, d f=7, P<0.001,\end{array}$ & $\begin{array}{l}\text { Sparse canopy cover } \\
\text { Sparse mid-level cover }\end{array}$ & "Parkland"/partially cleared \\
Dense low-level cover & $\begin{array}{l}\text { areas at all altitudes with } \\
\text { remnants of secondary or } \\
\text { pome large trees }\end{array}$ & primary forest \\
& Low tree density & \\
Ptilinopus dohertyi & High altitude & High altitude and relatively \\
$\chi^{2}=82.22, d f=12, P<0.001$, & Tall trees & undisturbed primary forest \\
$\%=80.1$ & Many trees branching above & with fruiting trees
\end{tabular}

Cacatua sulphurea

$\chi^{2}=37.33, d f=8, P<0.001$
$\%=74.6$

Eclectus roratus

$\chi^{2}=50.85, d f=13, P<0.001$,
$\%=76.0$

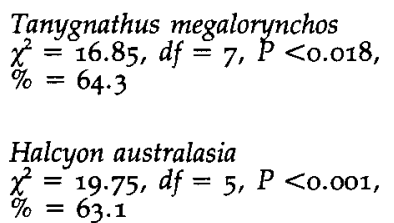

Rhyticeros everetti

$\chi^{2}=29.94, d f=9, P<0.001$

$\%=71.8$

Pitta elegans

$\chi^{2}=27.30, d f=5, P<0.001$

$\%=73.4$

\section{Coracina dohertyi}

$\chi^{2}=40.13$, df $=10, P<0.001$, $\%=76.65$

$$
\begin{aligned}
& \text { Zoothera dohertyi } \\
& \chi^{2}=100.7^{2}, d f=9, P<0.001 \\
& \%=82.8
\end{aligned}
$$

$$
\begin{aligned}
& \text { Rhinomyias oscillans } \\
& \chi^{2}=15.83, d f=7, P<0.027 \\
& \%=68.6
\end{aligned}
$$

High tree density

Few trees branching below

Low altitude

Near to water

Sparse low-level cover

Few trees branching below

Sparse ground cover

Few dead trees

Low altitude

Little tree regeneration

Low tree density

Steep slopes

Sparse ground cover

Few deciduous trees

Low altitude

Low tree density

Low canopy cover

Few deciduous trees

High tree density

Few dead trees

High biomass

Little tree regeneration

Many deciduous trees

Few deciduous trees

Large-girthed trees

Low altitude

Sparse ground cover

Dense canopy cover

Sparse low-level cover

Dense ground cover

Few dead trees

Steep slopes

Sparse canopy cover

Many trees branching below

Sparse low-level cover

Little tree regeneration

Large-girthed trees

Dense canopy cover

Sparse ground cover

Tall trees

High altitude

High tree density

Tall trees

Many trees branching above

Few trees branching below

Dense canopy cover

Next to paths

Many trees branching below

Dense low cover

Few trees branching above

Tall trees

High altitude
Primary forest at low altitudes in valley bottoms

Secondary evergreen forest at low altitudes on steep slopes

Open evergreen forest at low altitudes

Dense forest with deciduous trees which has not recently been disturbed

Low altitude, closed canopy, evergreen forest, primary or mature secondary

Open secondary forest with dense undergrowth on steep slopes

Closed-canopy forest at all altitudes, primary or mature secondary

High altitude primary forest

High altitude and fairly mature secondary forest and forest edge 
Table 6. - contd.

\begin{tabular}{|c|c|c|}
\hline & Discriminating variables & Interpretation \\
\hline $\begin{array}{l}\text { Ficedula harterti } \\
\chi^{2}=10.24, d f=5, P<0.069, \\
\%=63.5\end{array}$ & $\begin{array}{l}\text { Some large trees } \\
\text { Sparse ground cover } \\
\text { High tree density } \\
\text { Few trees branching below } \\
\text { Many trees branching above } \\
\text { Dense canopy cover }\end{array}$ & $\begin{array}{l}\text { A weak preference for prim- } \\
\text { ary forest }\end{array}$ \\
\hline $\begin{array}{l}\text { Nectarinia buettikoferi } \\
\chi^{2}=73.13, d f=6, P<0.001 \\
\%=79.2\end{array}$ & $\begin{array}{l}\text { Low altitude } \\
\text { Low tree density } \\
\text { Few trees branching above } \\
\text { Many trees branching below } \\
\text { Short trees } \\
\text { Sparse canopy cover }\end{array}$ & $\begin{array}{l}\text { "Young" secondary forest } \\
\text { and scrub at low altitudes }\end{array}$ \\
\hline $\begin{array}{l}\text { Zosterops wallacei } \\
\chi^{2}=51.68, d f=9, P<0.001 \\
\%=68.81\end{array}$ & $\begin{array}{l}\text { Low altitude } \\
\text { Sparse canopy cover } \\
\text { Dense low cover } \\
\text { Low tree density } \\
\text { Near to water } \\
\text { Many trees branching below }\end{array}$ & $\begin{array}{l}\text { Open secondary forest and } \\
\text { scrub with dense under- } \\
\text { growth near to water }\end{array}$ \\
\hline $\begin{array}{l}\text { Myzomela erythrocephala } \\
\chi^{2}=32.94, d f=6, P<0.001 \\
\%=68.12\end{array}$ & $\begin{array}{l}\text { Near to paths } \\
\text { Many deciduous trees } \\
\text { Flat ground } \\
\text { Many trees branching above } \\
\text { High tree density } \\
\text { Few trees branching below }\end{array}$ & $\begin{array}{l}\text { Edges of deciduous primary } \\
\text { forest }\end{array}$ \\
\hline
\end{tabular}

See Table 5 for correlation coefficients and Table 7 for mean and standard deviations of each of the habitat variables.

The significance of the difference between the habitat at stations where a species was, and was not, recorded is indicated by the $\chi^{2}$ analysis. The \% refers to the percentage of stations correctly assigned to positive and negative groups by the Discriminant Function Analysis.

ing", above) of the measured habitat variables. In this case DFA is used firstly to highlight any consistent differences in the habitat between the positive (species recorded) and negative (species not recorded) stations, and secondly to identify which of the habitat variables are most closely allied to the presence or absence of each bird species.

Table 5 contains the basic results of the DFA. Shown for each species are the correlation coefficients of each habitat variable with the discriminant function. A high positive coefficient indicates that high values of a variable (e.g. dense rather than sparse canopy cover) are associated with the presence of a species at the census stations. A high negative coefficient suggests that low values of a variable (e.g. a sparse canopy cover) are associated with species presence. Low coefficients (positive or negative) indicate that a variable is not associated with the presence or absence of a particular bird species. The results in Table 5 are interpreted in Table 6, where the most important habitat variables are used to construct a habitat profile for each species. It was arbitrarily decided to take the six highest coefficients to construct the habitat profile. The only exception was for Treron teysmanni, where only five variables had significant correlations (i.e. coefficients which were greater than 0.200 and were thus significant at the 0.01 level). The correlation coefficients do not indicate causal relationships between habitat features and birds; they just describe the environment where individual species are present or absent. Presenting the correlations (rather than the Standardized Discriminant Function Coefficients) also does not highlight any interactions between the variables. For example, areas with large trees may 
Table 7. Mean values of the habitat variables used in the discriminant function analysis

\begin{tabular}{llrr}
\hline Variable & Units/explanation & Mean & $\begin{array}{c}\text { Standard } \\
\text { deviation }\end{array}$ \\
\hline Altitude & $\mathrm{m}$ & 541.96 & 243.49 \\
Canopy cover & $\%$ & 33.17 & 19.60 \\
Mid-cover & $\%$ & 41.62 & 17.00 \\
Low cover & $\%$ & 37.41 & 20.63 \\
Ground cover & $\%$ & 28.74 & 27.06 \\
Largest girth & $\mathrm{m}$ & 2.47 & 1.26 \\
Mean girth & $\mathrm{m}$ & $\mathbf{1 . 1 2}$ & 0.27 \\
Mean height & $\mathrm{m}$ & 22.09 & 4.89 \\
Tree density & Trees per $\mathrm{m}^{2}$ & 0.02 & 0.02 \\
Branch below & No. out of 1o & 5.34 & 3.11 \\
Branch above & No. out of 10 & 5.56 & 3.08 \\
Regeneration & No. out of 10 & 4.91 & 3.05 \\
Deciduous & No. out of 10 & 2.18 & $\mathbf{2 . 9 3}$ \\
Dead & No. out of 10 & 0.34 & 0.69 \\
Fruiting & No. out of 10 & 0.08 & 0.51 \\
Water & Distance in km & 0.39 & 0.98 \\
Slope & Degrees & 24.51 & 16.04 \\
Path & Width in metres & 1.59 & 1.09 \\
Biomass & m of wood per $\mathrm{m}^{2}$ & 0.09 & 0.11 \\
\hline
\end{tabular}

be important for a species, but perhaps because these areas are less disturbed rather than because tree size is important per se.

In interpreting the DFA results we suggest that an association with primary forest is indicated by correlations with a high percentage of trees branching above half their height, large trees and a dense canopy. A secondary forest association would be indicated by a high percentage of trees branching below half their height. There are obviously many different types of secondary forest, and factors such as tree size and density, canopy and ground covers are used as indicators of closed or open forest and mature or recently disturbed forest.

The mean and standard deviation of each of the habitat variables (Table 7) also aids in the interpretation of the DFA. For example, the mean altitude of the stations is $542 \mathrm{~m}$, so any attribution of high or low altitude to a species refers only to whether it was more often seen at altitudes above or below this mean value.

The results in Table 6 highlight some quite specific habitat associations: Ptilinopus dohertyi and Zoothera dohertyi, although recorded in most forest areas, show a strong preference for high altitude primary forest; Cacatua sulphurea and Rhyticeros everetti are strongly associated with primary or mature secondary evergreen forest at low altitudes, and Myzomela erythrocephala shows a preference for the edges of primary forest with a "high" deciduous content (but bearing in mind that two deciduous trees per station is the mean value for all stations). The rest of the restricted-range species are associated with secondary forest (except Ficedula harterti, but see later), but the DFA highlights specific preferences within that habitat category. Some species such as Coracina dohertyi were most frequent in closed-canopy secondary (and perhaps also primary) forest, whilst others such as Nectarinia buettikoferi and Zosterops wallacei were associated with open secondary forest and scrub. Tanygnathus megalorynchos is also associated with 
open secondary forest (at low altitudes), but this is still within forest rather than forest edge. The results for each species are considered further, together with any other relevant information, in the species account section.

Another statistic shown in Table 6 is the $\chi^{2}$ value and associated probability for each DFA. The $\chi^{2}$ analysis indicates whether there is a significant discrimination between the habitats at the positive and negative stations. For Ficedula harterti this discrimination is not significant so we cannot say anything definite about the species's habitat preferences. The discriminations for Rhinomyias oscillans and Tanygnathus megalorynchos were only just significant at the 0.05 level $(P=$ 0.027 and $P=0.018$ respectively), but for all the other species probability values of less than 0.001 indicate very highly significant discriminations between the habitats at positive and negative stations.

Once the DFA has selected the group of variables which maximize the difference between positive and negative stations (the "discriminant function"), the stations can be reclassified according to that function. The percentages shown in Table 6 are the results of this reclassification. For example, for Ptilinopus dohertyi, $80.1 \%$ of the stations can be correctly classified as positive or negative for the species just from the appropriate set of the habitat variables. The misclassified stations were those which either had suitable habitat and no $P$. dohertyi recorded or did not have suitable habitat (according to the DFA analysis) but still produced a record for the species. The former reason, suitable habitat but no bird record, was the major cause of mis-classification for all of the species. There are two possible explanations for this. Probably the main one is that our classification into positive and negative stations could be dependent on only two 10-minute visits to a station (although most stations had at least two visits). Repeated visits to stations would have provided a much more reliable classification into positives and negatives and much higher proportions of stations correctly assigned. The second explanation is that splitting the census stations into positive and negatives implies saturation of the habitat, and if a species is not at its maximum density there are almost certain to be a number of "false positive" stations (Capen et al. 1986).

The lowest percentage of stations correctly classified was $63.5 \%$ from a nonsignificant DFA for Ficedula harterti. Three other species of small insectivores/ omnivores, Rhinomyias oscillans, Zosterops wallacei and Myzomela erythrocephala, together with Tanygnathus megalorynchos and Halcyon australasia, also had lower percentages correctly classified. It is possible that the scale at which we collected the habitat data was more appropriate for the larger species (over $70 \%$ correctly classified for all bar one of the non-passerines), and this is currently being investigated (see also Wiens et al. 1987).

\section{Population densities}

Population densities were calculated for species in two habitat categories, forest and forest edge. Further subdivision of the forest category into (e.g.) primary and secondary forest or evergreen and deciduous forest was avoided. The main reasons for this were (1) to increase the sample size in the hope of producing more reliable estimates for each species, (2) to avoid a subjective division into different forest types, and (3) because data on forest cover on Sumba were only 
available for broad habitat categories and not for primary, secondary, evergreen forest, etc.

The population density estimates are shown in Table 8 . Three of the restricted-range species (Turnix everetti, Ninox rudolfi and Muscicapa dauurica) do not appear in this table because they were never, or rarely, seen at any of the census stations (at least five contacts are needed to calculate an estimate). For some of the other species an estimate was possible for the forest but not the forest-edge stations. The species with the lowest densities in forest are the three large parrot species, namely Eclectus roratus ( $1.2 \pm \mathrm{SE} 0.3$ per $\mathrm{km}^{2}$ ), Tanygnathus megalorynchos (1.3 $\pm \mathrm{SE} 0.5$ per $\left.\mathrm{km}^{2}\right)$ and Cacatua sulphurea $\left(2.2 \pm \mathrm{SE} 1.1\right.$ per $\left.\mathrm{km}^{2}\right)$. The species with by far the highest density is Nectarinia buettikoferi (445.9 \pm SE 70.4 per $\mathrm{km}^{2}$ in forest and $157.6 \pm$ SE 19.9 per $\mathrm{km}^{2}$ in forest edge). The endemic species with the lowest densities are Rhyticeros everetti $\left(5.7 \pm \mathrm{SE} 1.6 \mathrm{~km}^{2}\right)$ and Ptilinopus dohertyi $\left(6.9 \pm \mathrm{SE} 1.2\right.$ per $\left.\mathrm{km}^{2}\right)$. Although the standard errors for most species are reasonably small, more data are obviously required to increase the precision of the estimates, particularly for the forest edge habitat.

There are a number of reasons, specific to this study, why some of the density figures may be marginal or even serious underestimates. The first reason concerns the problem of birds in flight. Point counts should produce a "snapshot" of the birds at a census station but in practice, in order to sample fully the area around each station, 10 minutes is spent recording birds. This obviously provides time for birds from other areas to fly into, or over, the sampling area and inflate the population estimates. The flying contacts, therefore, have to be excluded and there is at least a possibility that this might reduce the estimates below the "real" figures. For the majority of species this is not a problem, as less than $5 \%$ of the total contacts were with flying birds. For four species, however, a significant proportion were flying: $59 \%$ for E. roratus and T. megalorynchos, $45 \%$ for $C$. sulphurea and $26 \%$ for $R$. everetti. The exclusion of these contacts also greatly reduces the sample sizes.

A second cause of underestimation is a combination of the fact that most of the census contacts were aural and that such contacts often underestimate group size for gregarious species. The degree of underestimation is calculable by first comparing the group sizes of visual and aural contacts and then, by using the appropriate ratio, multiplying up the group size for the aural contacts. How much this then affects the estimation of density depends on what percentage the aural contacts make up of the total contacts for a species. Further details are given in the next section where total population sizes are calculated.

A third reason why the densities of the species may be underestimated is that breeding female birds may be under-recorded. We know from direct observations that some species were breeding at the time of the fieldwork, and it is likely that birds spending time at nests or in nest holes are less likely to be recorded, and singing males more likely to be recorded. In most cases it is impossible to estimate the proportion of the population that would be affected. For $E$. roratus, one of the few species which could be sexed, of all the individuals seen only $30 \%$ were females, which is significantly different from the expected $50 \%\left(\chi^{2}=29.62, d f=1, P<0.001\right)$. This is probably because many females were sitting in nest holes and did not form part of the censused population. For two 


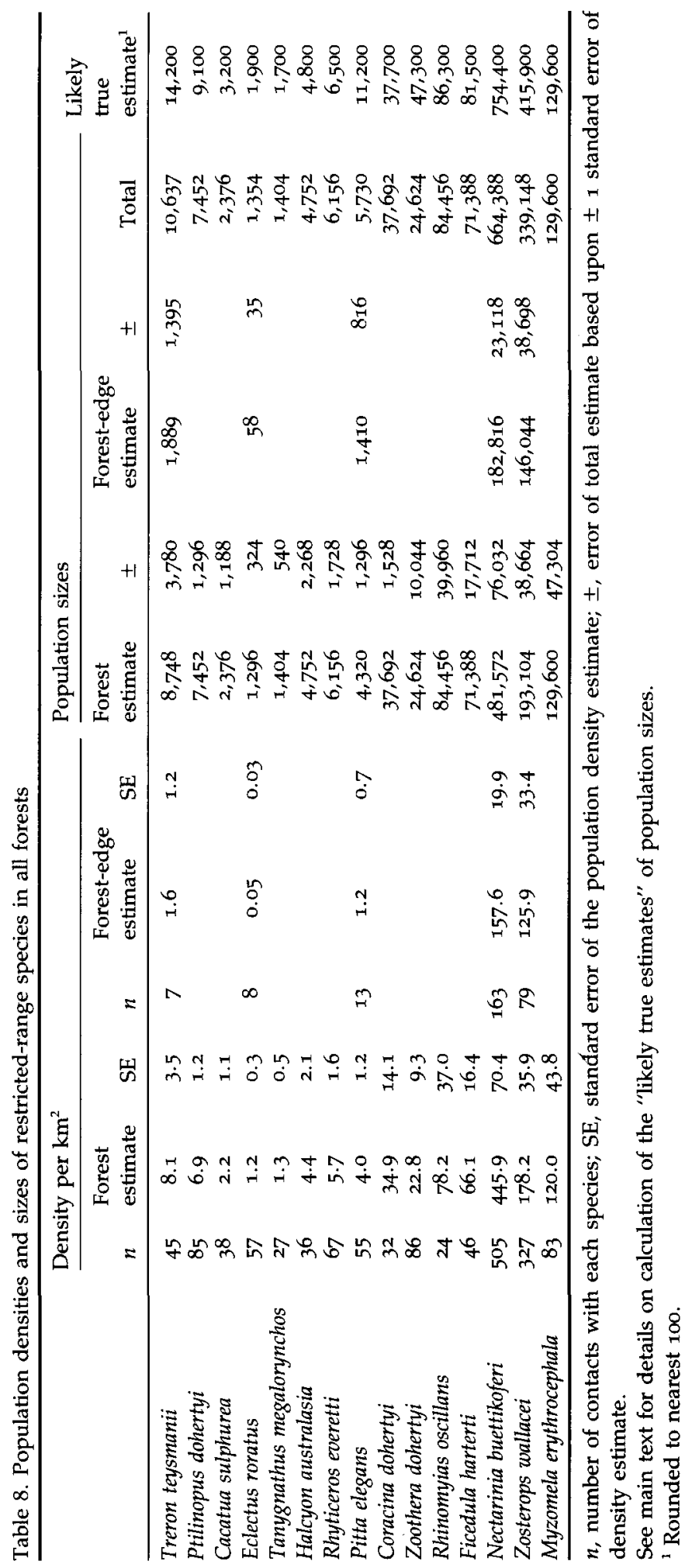


species, Pitta elegans and Zoothera dohertyi, there is no doubt that females were under-recorded as the great majority of contacts were with singing males (there were very few sight-only contacts for both species).

\section{Total population estimates}

Table 8 shows an estimate of the population size in forest and, when possible, forest-edge habitats for each of the restricted-range/endemic species. Initially these were calculated by multiplying the original density estimates by the area of either forest (closed-canopy) or forest-edge habitat on Sumba. Through interpretation of satellite photographs, McKnight et al. (in prep.) estimated the coverage of closed-canopy forest to be $1,080 \mathrm{~km}^{2}$. P. Jepson (in litt. 1994) states that a further $600 \mathrm{~km}^{2}$ has some tree cover and that there is also $560 \mathrm{~km}$ of gallery forest. As a very rough estimate of the coverage of our "forest-edge" habitat we have added these two figures together to produce a total of $1,160 \mathrm{~km}^{2}$.

The "total" population size in Table 8 was calculated by adding together the estimates for forest and forest-edge habitats. Although no estimates were possible for some species in the forest-edge habitat, they were still seen in such areas and would not have contributed to the total estimates. This is probably balanced by the fact that isolated patches of forest were included in the closedcanopy total; such areas might support much lower densities of the forestdependent species than were calculated by our data collection in the "large" forest patches.

By comparing the population densities and sizes with the results of future surveys it will be possible to identify any changes in the populations of the restricted-range species. The figures can also be used to compare with studies using the same methods on similar islands and bird faunas. However, the "total" population estimates do not take into account the factors which may have led to underestimation of some species' densities (outlined in the previous section) and may not be the most reliable guide for identifying which species are most at risk from extinction. The "likely true estimate" in Table 8 attempts to rectify this. The estimate for each species was first modified by calculating the mean group size for visual contacts and then using this figure to replace each group size for all aural contacts. The total estimates were then recalculated with the new group sizes. For Halcyon australasia, Pitta elegans, Coracina dohertyi, Zoothera dohertyi and Myzomela erythrocephala visual and aural group sizes were on average the same, so their estimates are not affected. A further modification was made for $P$. elegans and $Z$. dohertyi as these are the two species for which the majority of contacts were singing males. For both species the ratio of visual to aural contacts (the latter being the singing males) was used to divide the estimate into a portion deriving from visual contacts and a portion from aural contacts. The latter number was then doubled and added to the visual contact portion. It is likely that a similar procedure should also be applied to the estimates for $P$. dohertyi and $H$. australasia, but the division into singing male and other contacts is not so clear-cut.

Examination of the "likely true estimates" (rounded to the nearest 100 in Table 8) suggests that Eclectus roratus, Tanygnathus megalorynchos and Cacatua sulphurea are certainly the species at greatest risk of extinction. Halcyon 
australasia is also rare but there is the possibility that its population has been underestimated. Populations of the endemic Rhyticeros everetti and Ptilinopus dohertyi are the next lowest but may not be so seriously threatened as the parrot species. The three smallest passerines, Nectarinia buettikoferi, Zosterops wallacei and Myzomela erythrocephala, have large or very large populations and are not endangered. The status of each species is discussed in more detail in the next section.

\section{Species accounts}

In this section the results of the bird population and habitat analyses are combined with any other relevant information available for each species. The reason for presenting as complete a picture as possible is that many of the species are very poorly known. Taking all the information together, an assessment of the "category of threat" for each species is made according to the provisional criteria in Mace et al. (1992). Each threat category is followed by a letter which indicates which criterion has been satisfied in the adoption of a particular category. For the species which we did not record on formal censuses, the assessment of extinction risk depends solely on previous workers and our own general records and observations.

\section{Sumba Button-quail Turnix everetti}

Prior to our visit in $1989 T$. everetti was known only by three museum specimens. We recorded up to six and mist-netted one male at Yumbu, near Watumbaka (see Figure 1). The habitat was sparse grassland with occasional bushes on a flat plateau of coral limestone directly behind the mangrove belt. In 1992 up to 17 birds, and one T. maculosa (Red-backed Buttonquail) were seen in approximately the same area and in the same habitat as in 1989. Another record of $T$. everetti from Manupeu was of a bird in grassland. There were also records of Turnix spp. in grassland at all of the other study areas. Among the sightings at Langgaliru was an individual positively identified as T. maculosa.

This appears to be the only endemic species on Sumba which is not reliant to some degree on tree cover; its ecology remains very little understood but it obviously depends on grassland. The definite, and possible, records refer to birds in areas with a sward height of between 0.5 and $0.7 \mathrm{~m}$ with interspersed areas of shorter grass. The impact of burning on the bird's preferred habitat is problematic - it is possible that burning in the past has actually increased the area of suitable habitat.

No T. everetti were recorded at stations (there were very few stations in open grassland), so no estimates are possible. Considering that the species is small and elusive and that high densities were encountered (at least in one area) we can posit that it is not threatened. A firm decision will obviously depend on specific research. Category of threat: Insufficiently Known.

\section{Sumba Green-pigeon Treron teysmanni}

This endemic green-pigeon is the only Treron species recorded on Sumba. Recorded in small numbers by both Zieren et al. (1990) and M. Riffel and D. 
Bekti (in litt.) and at all of our study sites except Wanggameti. Usually recorded as singles, pairs or small groups but at the Nerip site in Langgaliru up to 12 birds were seen feeding on the fruit of adjacent trees of Streblus asper and Ficus benjamina. The birds returned to the same positions in the same trees over a seven-day period. Individuals or pairs set up territories each day and defended them intraspecifically and against other species, e.g. Ptilinopus melanospila (Black-naped Fruit-dove) and Aplonis minor (Short-tailed Starling) (C. King verbally).

Although seen in a wide variety of areas and habitats, the DFA and other analyses suggest that this species may still have a fairly precise habitat association. Treron teysmanni is most likely to be recorded in tree canopies in forest or on the edges of forest which has been opened up for some reason. These areas may have low tree densities but the trees are usually large and the habitat would probably still be classified as closed-canopy (at least from satellite photographs). The disturbance of Sumba's forests, and the increase in secondary growth and edge habitat, may explain why this species is still fairly common. It is also possible to speculate that forest disturbance has increased the availability of fruit for $T$. teysmanni.

The widespread occurrence of this endemic species, its preference for a relatively common habitat and its likely population size (probably over 14,000) indicate that this is not a threatened species. However, it has presumably declined with the clearance of forest and would be seriously affected by further clearances. Category of threat: Susceptible.

\section{Red-naped Fruit-dove Ptilinopus dohertyi}

One of only two single-island endemic fruit-dove Ptilinopus species in the whole of Wallacea (White and Bruce 1986). Two individuals were seen by Zieren et al. (1990) and at least 14 by M. Riffel and D. Bekti (in litt.) in primary forests. Of the two sites we visited in 1989 this species was only recorded at Tabundung, with less than 10 observations, all within or close to primary forest. Mainly seen in singles in the canopy of large forest trees. It was difficult to see at rest and to identify in flight, and no vocalizations were identified. Recorded much more frequently in 1992, partly because vocalizations were definitely identified, but there were also many more sight records. Seen at all study sites in primary and secondary forest, with most records from higher altitude sites like Wanggameti and Yawila. Although there appeared to be an association with high-altitude forest, in 1992 we still recorded the species at lower altitudes, often down to $200 \mathrm{~m}$ and occasionally down to $160 \mathrm{~m}$.

These general observations - an association with primary forest at higher altitudes - is confirmed by the habitat analyses. The DFA suggests a particularly strong association with high altitude. This species is, therefore, an exception to the trend highlighted by White and Bruce (1986), who state that a distinctive character of Wallacea is that a montane non-passerine component is very poorly represented and "almost absent in the Lesser Sundas".

Although fairly widespread with a reasonably sized population of over 9,000 (which may be underestimated), $P$. dohertyi is probably at a greater risk than 
the preceding species because of its narrower habitat range. It has presumably also suffered greatly from the past decline in forest cover. Category of threat: Vulnerable $(C, D)$.

\section{Sulphur-crested Cockatoo Cacatua sulphurea citrinocristata}

At one time this endemic subspecies was probably very common on Sumba (Hartert 1896) and even quite recently Kendall (1979) records that cockatoos could indeed be seen on the outskirts of Waingapu and were locally hated for their depredations on maize crops. FAO (1982), Zieren et al. (1990), M. Riffel and D. Bekti (in litt.) and D. A. Holmes (in litt.) all report sightings in widespread areas and in both primary and secondary forests. M. Riffel and D. Bekti (in litt.) also state that $C$. sulphurea was obviously not restricted to primary forest and that it was never encountered deep inside the forest.

In $1989 \mathrm{C}$. sulphurea was fairly frequently recorded at both study sites. Long watches from vantage points at the two study sites allowed observations of general behaviour and activity. At Tanjung Ngunju all but one of the $34 \mathrm{C}$. sulphurea sightings were of birds alighting from, or flying to, forest. At Tabundung, this was $86 \%$ of 97 sightings. These data suggest that, contrary to Riffel and Bekti's conclusions, this species is heavily dependent upon closed-canopy forest. In 1992, C. sulphurea was again frequently recorded and at all study sites.

The results of the DFA strongly support the association of $C$. sulphurea with primary forest at low altitudes. The records of this species in other areas may be of birds flying between forest patches. Marsden (in prep.) includes the following information on C. sulphurea nests: of a total of 46 active or old nests located (in August, September and early October), all but two were in deciduous trees and $68 \%$ were in two tree species of the family Datiscaceae; many of these trees held nests of other parrot species and the mean DBH of trees with nests was $0.92 \mathrm{~m}$. The areas with highest $C$. sulphurea densities, e.g. Manupeu, are largely evergreen forests and in these areas it is the relatively few deciduous trees (usually emergents) which are selected for nesting.

The fact that the species is both vocally and visually conspicuous and very mobile probably explains why, although fairly regularly seen, it has a small estimated population (just over 3,000). There can be no doubt, therefore, that this endemic subspecies of $C$. sulphurea is seriously, and perhaps critically, endangered on Sumba. Although habitat loss has probably been the main cause of its long-term decline, capture for the cage-bird trade may have had an increasing effect as the population declined to a very low level. Although it is now against the law to capture $C$. sulphurea for the export trade, our observations confirm that illegal trade is continuing. Strictly enforcing the law is obviously essential for the species's continued survival. At least as important is the preservation of the large trees it needs for successful breeding, and the younger trees of the relevant species which will provide suitable nest-sites in the future (Marsden in prep.). Even within areas of suitable forest the distribution and population densities of $C$. sulphurea are probably determined by the availability of nest-holes which cannot be climbed to by local bird-catchers. Category of threat: Endangered (B,D). 


\section{Eclectus Parrot Eclectus roratus cornelia}

Kendall (1979) describes seeing this endemic race in pairs in moderately dense forest with numerous very tall trees near Melolo (East Sumba) in February 1978. It was reported to be common in Manupeu forest, with a single female also seen in Praipaha forest during January and February 1990 (Zieren et al. 1990). $M$. Riffel and D. Bekti (in litt.) recorded nine birds, all males, during a threeweek visit in August 1991. Most observations were in the vicinity of primary forest but they added that birds frequently fly to open country to feed, and concluded that $E$. roratus "is obviously the rarest Psittacine species on Sumba".

In 1989 and $1992 E$. roratus was recorded in all study areas in primary and secondary forest and in parkland and forest edge. Birds were also seen away from large forest blocks, even in isolated and highly disturbed forests and areas of scrub. Birds were usually recorded in singles or twos but occasionally in small mixed-sex groups. The largest aggregation was of two females and five males in old secondary forest at Tabundung.

The results of the DFA for this species are open to a number of interpretations but we can definitely say that this species does not show an exclusive association with primary forest. Low-altitude, evergreen, secondary forest would seem to be preferred, but our general observations show that other areas are still utilized. Of 31 nests located (Marsden in prep.) all but one were in deciduous trees (mean DBH of $1.2 \mathrm{~m}$ ) and $83 \%$ were in two tree species of the family Datiscaceae. Several trees contained more than one $E$. roratus nest and one tree had four active nests.

Although $E$. roratus may never have been subject to the same level of trade as C. sulphurea, it may be rarer. This perhaps highlights the role of habitat destruction in the probable decline of parrot species in general. As with $C$. sulphurea and other hole-nesting species, protection of nest-trees and lowland forest may be crucially important. At least 21 birds, mostly female, were seen in captivity in Waingapu and Melolo and this continued trade should, if possible, be curtailed. Although the estimate of 1,900 may be lower than the actual population size (depending on the effects of excluding all the flying contacts) this subspecies is at great risk of extinction. Category of threat: Endangered (B,D).

\section{Great-billed Parrot Tanygnathus megalorynchos sumbensis}

There is very little information on the ecology of $T$. megalorynchos from anywhere in its range in Indonesia and Papua New Guinea (see Forshaw 1989). On Sumba one pair was observed in lowland forest by Zieren et al. (1990) and 27 were recorded by $\mathrm{M}$. Riffel and D. Bekti (in litt.) in 1991. The latter described the species as fairly common in parkland, secondary and primary forests.

In 1989 records came from Casuarina forest at Baing, primary forest at Pengaduhahar and primary and secondary forest at Tabundung. Recorded at all sites in 1992, generally in small numbers (one to three). Exceptions to this were at one section of the Luku Melolo valley where 10-12 were regularly seen, at Nerip where $7^{-11}$ were seen on three days and at Matayangu, where a group of 14 , possibly flying to roost, was seen on two days. Occupied nests were found at 
the Tabundung, Nerip, Pornumbu and Wanggameti study sites, as well as at Langgaliru and Waimangura (Marsden in prep.). All of the nests were in large deciduous trees (mean $\mathrm{DBH}=0.95$ ).

The habitat analyses suggest that $T$. megalorynchos is associated with open forests at low altitudes. It is interesting that the DFA highlights a preference for evergreen forest yet all of the nests located were in deciduous trees. This indicates that either there is a difference between the preferred feeding and breeding areas or that the preferred habitat is forest which is predominantly evergreen but which also has a scattering of large deciduous trees. The distribution of records suggest that the latter is the case.

Although by no means restricted to primary forest, this species would be very vulnerable to further forest clearance and particularly to the loss of some of the largest trees. This, together with the fact that $T$. megalorynchos has the lowest estimate of all of the restricted-range species $(1,700)$, suggests that the Sumba subspecies is in serious danger of extinction. Category of threat: Endangered $(B, D)$.

\section{Cinnamon-banded Kingfisher Halcyon australasia australasia}

This species was not recorded by M. Riffel and D. Bekti (in litt.) or D. A. Holmes (in litt.). In 1989 our only record was of one bird in a tree in grassland, near a patch of primary forest, at Tabundung on 10 October. In 1992 recorded daily in small numbers at all study sites, usually in forest but sometimes in forest edge.

The habitat analyses suggest the species is found at low, mid- and canopy levels within dense forest that has a higher than average deciduous element. The population estimate of less than 5,000 may be an underestimate as the censuses could be biased towards calling/singing males. Nevertheless, with a relatively low population centred in dense forest the species is probably at some risk of extinction through further habitat loss. Category of threat: Vulnerable $(\mathrm{C}, \mathrm{D})$.

\section{Sumba Boobook Ninox rudolfi}

Ninox rudolfi is listed for the lowlands of Sumba, to at least $500 \mathrm{~m}$ (White and Bruce 1986). One was observed at night at a parkland fire at Mondu by M. Riffel and D. Bekti (in litt.).

The only confirmed record in 1989 was of one brought to our camp by a cockatoo catcher at Tabundung. It had been caught in one of the catcher's nylon snares set on the edge of closed-canopy forest. Recorded more frequently in 1992 with one seen in disturbed primary forest near Nerip, one in mature deciduous forest west of Waikabubak, four seen in secondary forest at Puronumbu and two seen in disturbed primary forest at Wanggameti. All sightings were diurnal.

Although this species was not seen often enough at census stations to enable DFA to be carried out, records indicate an association with forest of all types deciduous and evergreen, primary and secondary. A bird was observed returning repeatedly to a probable nest cavity in a huge tree (family Datiscaceae) at Wondu, Langgaliru. 
It is only possible to guess at the status of this species and more research is obviously needed. It is apparently adaptable to different forest types but has only been recorded in a few locations. Category of threat: Susceptible/Insufficiently Known.

\section{Sumba Hornbill Rhyticeros everetti}

FAO (1982) reported this endemic species to be scarce to not uncommon in two forests visited. Zieren et al. (1990) suggest that it was not common, but several pairs were observed in undisturbed forest. D. A. Holmes (in litt.) recorded three males in separate forest areas near Lewa. The majority of M. Riffel and D. Bekti's (in litt.) records were in the vicinity of large areas of primary forest. They added that concomitant with the ongoing habitat destruction, the trapping of $R$. everetti is a severe threat to this highly endangered species.

We recorded $R$. everetti at all study sites and usually in little-disturbed forest but occasionally birds were seen in forest edges and isolated patches of trees and even in single trees in fruit in cultivated areas. In 1992, it was most commonly seen at the Matayangu site in Manupeu forest where groups of 10, 14 and 15 were seen flying into fruiting trees. These large groups were mostly seen in the late afternoon, and the birds may have been moving slowly to communal roosts. For more information on the behaviour of $R$. everetti see Juhaeni (1993).

The DFA suggests a strong association with evergreen forest with large trees and a dense canopy at low altitudes. Such features would be found in primary forest or old secondary forest and are certainly characteristic of areas such as Manupeu and Langgaliru where the species was most frequently recorded. Ten nests were located (Marsden in prep.), all but two in living deciduous trees (mean DBH $=0.99 \mathrm{~m}$ ). The situation of this species is very similar to that the restricted-range parrots in that evergreen forest has the highest densities of birds but it is the scattered deciduous trees which are chosen for nesting.

There was little evidence of large-scale trapping of $R$. everetti. Two captive birds (both female) were seen in Waingapu and hunters near Waikabubak said that they did occasionally take the birds for food. However, local people at Yawila said that it was considered very unlucky to catch and kill the species. It is likely, therefore, that habitat destruction is the major threat to its survival. With a population estimate of 6,500 , this species is probably the rarest and most threatened of the endemic bird species of Sumba (although precise information is not yet available for Turnix everetti and Ninox rudolfi). Category of threat: Vulnerable $(\mathrm{C}, \mathrm{D})$.

\section{Elegant Pitta Pitta elegans maria}

There was previously no information on this endemic subspecies. White and Bruce (1986) state that other populations in the Lesser Sundas occur at forest edge and in woodlands and thickets to $1,000 \mathrm{~m}$.

Birds were commonly heard, but rarely seen, at Pangaduhahar, Praingkareha, Tabundung and Laiwangi in 1989. In 1992 recorded at all sites in all forest and forest-edge habitats (except mangrove). More frequently recorded at the west- 
erly sites but this may be a result of progression through the breeding season and an associated increase in singing activity.

The habitat analyses suggest a preference for dense undergrowth in open secondary forest on steep slopes with no obvious preference for particular altitudes. In terms of frequency of records this species is almost as common in forest edge as in forest itself (Table 3), but when the population densities are calculated (which take into account distance to contacts) the forest densities are much greater.

General observations suggest that this species may have a preference for the west of the island as it was particularly common at Manupeu, Puronumbu and Yawila.

With a population estimated to be over 11,00o and a wide habitat preference, this species is probably not in immediate danger of extinction. Category of threat: Safe/Low Risk.

\section{Sumba Cicadabird Coracina dohertyi}

Seen in small numbers at both study sites in 1989 in both primary and secondary forest. In 1992 it was seen at all sites in small numbers (one to two) usually from within forest. Most frequent at Puronumbu and Wanggameti.

The results of the analyses suggest that this is a species which inhabits midto high levels in closed-canopy forest. This forest has large trees with little sign of recent disturbance, suggesting that $C$. dohertyi is associated with either primary forest or mature secondary forest.

Although not commonly recorded (because of its secretive nature and quiet call) the birds located were usually close to census stations. This explains the relatively large estimate of over 37,000. Although $C$. dohertyi prefers closedcanopy forest, the size of its population suggests that it is not threatened at present. Category of threat: Safe/Low Risk.

\section{Chestnut-backed Thrush Zoothera dohertyi}

In 1989 the only records came from Tabundung where 11 singing birds were found along a $1 \mathrm{~km}$ stretch of path through primary forest. In 1992 five birds were caught in mist-nets in secondary forest at Luku Melolo and also recorded in disturbed primary forest at all other sites except Manupeu. Particularly common at the higher-altitude sites Yawila and Wanggameti with at least six birds recorded each day. Although there were some sight records (usually of birds which seemed to be feeding on the ground) most contacts were of birds singing or calling. Breeding was obviously not synchronized between the sites, as at Melolo two recently fledged birds were caught and there was no singing. At Yawila and Wanggameti many birds were singing.

The results of the analyses highlight a narrower habitat association than suggested by general observations: the birds are found at mid-levels in primary forest at high altitudes. Over $80 \%$ of the stations were successfully classified by a highly significant Discriminant Function which suggests that this association is particularly strong. The habitat analysis could have been affected by the differing levels of song and thus detectability in different sites and habitats. In this 
case, however, there is little difference in the results of the DFA if the aural contacts are excluded.

Although this species is concentrated in a restricted habitat - high altitude primary forest - its population is large (over 47,000 ), so the species is probably not threatened with extinction. Category of threat: Safe/Low Risk.

\section{Russet-backed Rhinomyias Rhinomyias oscillans stresemanni}

Not recorded by $M$. Riffel and D. Bekti (in litt.) and rarely seen in 1989 with two at Praipha and a nesting pair at Tabundung. More frequently recorded in 1992 with one to three seen almost daily at all study sites.

The analyses suggest an association with mid- to low levels in forest, and the DFA highlights a specific preference for the edges of mature secondary forest, usually at higher altitudes.

The relatively high population estimate (over 86,000 ) and the association with secondary forest suggest that the species is not threatened. Category of threat: Safe/Low Risk.

\section{Asian Brown Flycatcher Muscicapa dauurica segregata}

The endemic form present on Sumba is considered by Sibley and Monroe (1990) to be a full species, $M$. segregata. In this paper we follow Andrew (1992) in considering it an endemic subspecies of $M$. dauurica, but because of the uncertainty, its habitat associations and population sizes are considered here.

White and Bruce (1986) suggest that this species is scarce or local on Sumba and is usually found in lowlands up to $500 \mathrm{~m}$. M. Riffel and D. Bekti (in litt.) recorded four birds in the understorey of primary forest and saw none in secondary forest. It was not recorded by Zieren et al. (1990). D. A. Holmes (in litt.) recorded the species in forest remnants near Lewa. Only very rarely recorded in 1989 and 1992: a nesting pair on the border between cultivation and secondary forest at Tabundung and five other records from the edge of secondary forest.

None was recorded at stations so it was not possible to calculate population densities or analyse habitat associations. The little information available on habitat preferences is contradictory: Riffel and Bekti suggest it is a primary forest species but other observations suggest it is not. The general lack of records indicates that $M$. dauurica may be rare. This, together with the possibility that the Sumba form may be a full species, indicates that more information is needed on all aspects of its taxonomy and ecology. Category of threat: Insufficiently Known.

\section{Sumba Flycatcher Ficedula harterti}

Very little is known of this endemic species. Described as present at c.500 m, presumably in thickets, by White and Bruce (1986), but they add that no field data were available. Not recorded in 1990 by the Asian Wetlands Bureau team during brief searches of forest (Zieren et al. 1990), and also not recorded by $M$. Riffel and D. Bekti (in litt.). 
We found $F$. harterti to be quite common. It was recorded at all study sites, usually in low vegetation, in both little-disturbed forest and bushy secondary growth. Most frequently recorded at Tabundung in 1989 and Wanggameti in 1992 where an active nest with eggs was located. An adult was observed feeding two juveniles on 14 October in old secondary forest at Tabundung.

This was the only species for which the DFA could not find any significant relationships between "positive" stations and the habitat variables. One interpretation of this is that $F$. harterti has a wide preference and is therefore equally likely to be found in any of the forest areas. The other explanation is that we have failed to measure the critical factors or combination of factors which affect the species's distribution and/or have not measured the habitat variables at the appropriate scale. We can only be sure that this species is found in low vegetation and perhaps most often in primary forests, although many birds were caught in mist-nets in secondary forest. It seems to avoid scrub/grassland areas.

The relatively large estimated population (over 81,000 ) and the widespread occurrence of this species would suggest that it is not threatened. Category of threat: Safe/Low Risk.

\section{Apricot-breasted Sunbird Nectarinia buettikoferi}

Very little is known of this, the only single-island endemic sunbird in Wallacea. Several birds have been seen in Wanga Forest and in cultivation (Zieren et al. 1990), but it was recorded on only a few occasions (in forest-edge habitats) by M. Riffel and D. Bekti (in litt.).

We found the species to be very common. It was recorded on the edges of primary forest, in secondary forests and in cultivation mixed with scrubby secondary growth. It was not recorded from grassland areas with no trees. In terms of numbers of records this species was more frequent in forest edge than in the forest itself (Table 3), but when distance to contacts are taken into account (as in the calculation of population densities, Table 8) N. buettikoferi is actually more common within forests. The DFA analysis suggests that the favoured forest habitat is open/young secondary growth, particularly at low altitudes.

The estimated population size (over 750,000), widespread distribution and preference for "degraded" habitats indicate that this species is not threatened. Category of threat: Safe/Low Risk.

\section{Yellow-spectacled White-eye Zosterops wallacei}

Recorded sympatrically with $Z$. citrinellus (Ashy-bellied White-eye) at all study sites in 1989 and 1992. Found to be common and easily seen in primary and secondary forest and also in scrub away from the main blocks of forest. Rarer at Wanggameti where $Z$. citrinellus predominated. Joins mixed species feeding parties with flycatchers, monarchs and Myzomela erythrocephala.

The DFA suggests that the preferred habitat is mid- to high levels in secondary forest, often near water. This is obviously not a restrictive choice as the species was actually recorded in a wide variety of habitats.

With a fairly non-specific habitat association and a large population estimate (over 400,000 ) this species is obviously not threatened. Category of threat: Safe/ Low Risk. 


\section{Red-headed Myzomela Myzomela erythrocephala dammermani}

This endemic form is given species status by Sibley and Monroe (1990) but not by White and Bruce (1986) or by Andrew (1992).

Only two records from Tabundung in 1989, but seen at all study sites in 1992. Often seen on the edges of forest but also within primary forest with many deciduous trees, the exception to the latter being Wanggameti where the species was common in evergreen forest with Acacia spp.

The habitat analyses confirm the general observations. This is a forest species, found at mid- to high canopy levels at the edges of primary forest and, uniquely among the restricted-range species, it is associated with forest which has an above-average proportion of deciduous trees (although obviously this is not the case for Wanggameti).

Primary forest with a significant deciduous element, or forest similar to that found at Wanggameti, is not common on Sumba (at least in the areas visited), but because the species still has a large population (over 129,600) it is not threatened. Category of threat: Safe/Low Risk.

\section{Discussion}

\section{Methods of establishing bird-habitat associations}

The main way of identifying associations was through the use of Discriminant Function Analysis. This is an appropriate method to deal with a large number of habitat variables which are measured on, or transformed to, continuous scales (Haworth and Fielding 1988, Marsden 1992, Fielding 1993). An advantage of using DFA is that it obviates the need for an initial, and subjective, classification of habitat types. The regime adopted in this paper is still not completely objective because the initial choice of what to measure is subjective as is the final interpretation of the DFA to provide a habitat profile for each species. However, by providing the correlation coefficients associated with the analysis and the mean and standard deviation of each of the habitat variables (Tables 5 and 7), the results are available for interpretation by others.

One other subjective choice is of which areas and, more importantly, which habitats to study, and this has to be remembered when examining the results of the DFA. In this study our sample of habitats ranged from almost untouched primary to very heavily degraded forest, so the association of a species with, for example, dense canopy cover, can be interpreted as a "preference" for the less disturbed forests. If, however, we had sampled only in primary forest (which always has dense canopy cover) then that same species may have been associated with canopies below the mean value for the habitat. In this case there might be a tendency to suggest that the species prefers disturbed or even, by extension, secondary forest.

The habitats selected here were forest and forest edge (patches of forest mixed with scrub and grassland). The reason for this selection is that the great majority of the endemic and other restricted-range species were suspected of being 
forest-dependent (Jones and Banjaransari 1990). The result of the selection is that any preferences for pure grassland or scrub/grassland habitats will not be highlighted.

The data used for the DFA were incomplete because some stations received fewer visits and this no doubt led to mis-classifications of positive and negative stations. Nevertheless, high percentages of stations were still correctly classified with highly significant separations, and the analyses for most of the species are still interpretable in a biologically sensible way. DFA is thus a powerful tool for identifying bird/habitat associations.

The usefulness of DFA is not just restricted to the patterns it identifies in our particular data set: by using a subset of the variables (the most important as identified by the DFA) it would be possible to assess rapidly the suitability of other forest areas for a range of species. This would be especially useful when identifying areas into which a protected species might expand or in situations where bird census data were incomplete or bird identification skills lacking.

\section{Methods of estimating populations}

For a multi-species study such as this, the choice of point-count versus line-transect methods can be a very difficult one. Point counts are more suited to species which live in dense habitats and are less mobile, while line transects work better for mobile species (such as parrots) in more open habitats (Bibby et al. 1992, Buckland et al. 1993). Line transects are also advantageous in that more ground can be covered and smaller sample sizes may be needed (Buckland et al. 1993). Both methods were tested during our fieldwork in 1989 but only point counts were used in 1992 because (1) by standing still it was easier to find and conclusively identify birds in dense forest, (2) with fixed points it was possible to relate the occurrence of birds to specific habitat measurements (see also Bibby et al. 1992), (3) it was difficult, and not particularly safe, to concentrate on the location and identification of birds whilst travelling over the sometimes difficult terrain, and (4) it was impossible to estimate the distances between contacts and a line in front of the observer because of the density of the habitat.

Having chosen to use point counts, the reason for estimating the distance to each contact, rather than just recording its presence, is that it is then possible to calculate population densities. Simple point counts (and line transects) with no distance estimations will only produce encounter rates. These are sometimes of limited value in conservation studies as they are difficult to compare over time and between observers (see Lambert 1993). An important extra advantage of including distance data is that correction can be made for a detectability bias across species and habitats. From encounter rates alone it is difficult to make comparisons between species and to establish which are common and which are rare. For example, in this study, Eclectus roratus was recorded more frequently that Myzomela erythrocephala but has a much smaller estimated population. This is because $E$. roratus is very vocal and can be recorded over long distances while for $M$. erythrocephala, which is small and much quieter, all contacts were over short distances. In fact, taking all the restricted-range species 
together, there is no correlation $\left(r_{s}=0.113, n=15, P=0.688\right)$ between the rank orders of estimated populations in forest and the numbers of each species seen at forest stations.

Accounting for bias in detectability is obviously an important property of the methods but the crucial question is whether they actually produce reliable density estimates for each species. Various authors (e.g. DeSante 1986, Bollinger $e t$ al. 1988) have compared census-based estimates to "actual" population densities and have cast doubt on the accuracy of such estimates. Buckland et al. (1993) have indicated ways in which these authors' comparisons may not be valid due to practical and procedural problems. Nevertheless, although Bibby et al. (1992) and Buckland et al. (1993) have produced excellent treatments of the practical and theoretical basis for the census methods, there is still much research to be done on their reliability in a range of situations.

For this study, distances to individual contacts were estimated from points sometimes referred to as the variable circular plot method (Reynolds et al. 1980). Amongst the more important assumptions of the method (see Bibby et al. 1992 and Buckland et al. 1993) are that estimated distances to contacts are accurate and all birds at zero distance are detected. Another factor, that the detectability functions should have a "broad shoulder" (i.e. that the probability of detection remains nearly certain for at least some distance from the point), is not an assumption but is nevertheless essential for the calculation of accurate estimates (see Buckland et al. 1993).

The facts that the observers were highly experienced, that most bird contacts in tropical forest are over short distances, and that small but random errors may not have a very significant effect anyway, suggest that the distance estimations were probably accurate enough (it was impossible to use range-finders in this study because the forests were very dense and most contacts were aural). The likelihood of detecting all the birds at zero distance tends to be correlated with time spent at the census stations. Even hornbill and parrot species are easy to miss in the dense and high canopies above census stations, which is why a 10-minute recording period (longer than in most similar studies) was chosen. The production of a broad shoulder for the detection functions is also encouraged by this longer recording period as well as by having two observers at each station.

A critical consideration for accurate estimates is the sample sizes on which the calculations are based. Buckland et al. (1993) suggest that for point counts a minimum of $75-100$ contacts is required to achieve reasonable accuracy. Although recording took place at over 550 stations, and data from all forest areas were combined, because of the rarity of many of the species it was not always possible to obtain sample sizes of this magnitude. This is a problem which will be frequently encountered in conservation studies because target species are usually rare. This also underlines the fact that adequate data cannot be gathered quickly. The results of rapid surveys will neither produce reliable results in the short term, nor be useful for long-term comparisons. It may be possible to extrapolate results or to produce indices which are useful for a more rapid assessment of areas, but the basic data have to be adequate for this to be possible (see Lambert 1993).

In converting the population densities into total population sizes, another source of error or bias is the estimate of cover of suitable habitat and whether 
this study's habitat categories match those from the analysis of satellite photographs. More detailed data on forest cover are needed but this is only likely to come from analysis of the satellite data itself (rather than the images) or of aerial photographs. At present no account can be taken of the effect of altitude, and particularly the cover of each forest type in different altitudinal bands. In calculating both the population densities and habitat cover, figures have been averaged over all altitudes even though we know that many of the bird species have altitudinal preferences.

The population estimates produced in this paper will be subject to many sources of bias, some of which will be common to all studies using these methods, and others of which are peculiar to this study. Nevertheless we suggest that the methods used (point counts with distance estimation to each contact) are the most appropriate for multi-species studies in forest habitats, especially when precise information on habitat associations is required.

\section{Conservation priorities for Sumba's restricted-range species}

At present Cacatua sulphurea, Eclectus roratus and Tanygnathus megalorynchos are the rarest species and are classified as Endangered on Sumba. The first two may still be subject to illegal trade which may have a significant impact on such low population sizes. Another important consideration for the three parrot species and for Rhyticeros everetti (classified as Vulnerable) is that because they have delayed maturation, their effective breeding populations may be smaller than the estimated ones. Conversely, at least for the parrots, a low recruitment rate (because of capture of young birds for trade) may produce a high proportion of breeding birds but a population that is becoming increasingly geriatric (Rowley and Chapman 1991). C. sulphurea and $R$. everetti are also vulnerable through their dependence on primary or mature forest at low altitudes.

To protect these and the other restricted-range species (most of which are dependent on closed-canopy forest) it is obvious that the areas of remaining forest must be preserved. Of critical importance for the hornbill and parrot species and probably for Ninox rudolfi is that these protected forests should contain suitable nesting trees.

Further detailed research is obviously needed on both nesting and feeding ecology of the restricted-range species, particularly the parrots, the hornbill and perhaps the two pigeons. There is also still not enough information available even to assess the extinction risk for the two endemic species, Turnix everetti and $N$. rudolfi.

This paper's findings are based upon a dataset which is still too small for many of the species, and further research, particularly at different times of year and in different areas, might affect some of the conclusions made here. For this reason the results, particularly the population estimates, should not be quoted without qualification.

At the time of the fieldwork in 1992 there was only one protected area on Sumba, at Langgaliru. The results of this work (presented in more detail in Jones et al. 1994) are contributing to the conservation strategy for Sumba being prepared by the Direcktorat Jenderal Perlindungan Hutan Dan Pelestarian Alam (PHPA) and BirdLife International. This strategy will be presented to Nusa 
Tenggara's Governor and will include suggestions for the protection and management of more forest reserves.

\section{Acknowledgements}

We are very grateful to Huw Lloyd for helping to collect the bird census data and Dr Will Banham for his management of the whole expedition. We should also like to thank the following for their help in the planning and implementation of the fieldwork; Dr Leo Banilodu, Dr Tony Saka, Dr Frans Umbu Datta, Alex B. Ora, Yos L. Mame, Abdul Khair, Robert Umbu Rihi, Wahyu Raharjaningtrah, Hidayat Banjaransari, Dr Keith Hamer, Emma Harrison, Dr Jane Hill, Deddy Juhaeni, Dr Lesley Lace and Alison McKnight.

We are grateful for the considerable help and support we received from the following people and organizations: Effendy A. Sumardja (PHPA); Director Dr Soetikno Wirjoatmodjo, Dr Dedy Darnaedi, T. Hainald (Indonesian Institute of Sciences); Bas van Balen, Jonathan Eames, Richard Grimmett, Paul Jepson, Michael Rands and Shunji Usui (BirdLife International/Indonesia Programme); Derek Holmes, Paut Andrew (Ornithological Society of Indonesia); Carol and Tim Inskipp; David Bishop; Bas van Helvoort; Hiroshi Kobayashi; Fred Smiet; Donald Bruning (New York Zoological Society); Roland Wirth (ZSCSP); Max Zieren, Yus Rusila Noor and Mike Baltzer (Asian Wetland Bureau).

We are very grateful to the following persons/bodies who generously provided financial or material support: British Petroleum (through their support of the BirdLife International/Fauna and Flora Preservation Society Conservation Expedition Awards); BirdLife International (Cambridge and Indonesia); Environmental Management Development in Indonesia; Oriental Bird Club; Manchester Metropolitan University; Manchester Geographical Association; Chester Zoo; Douglas and Bridget Busk Fund; 27 Foundation; Zoological Society for the Conservation of Species and Populations; Young Explorers Trust; Zochonis Foundation; Birding World and the Biological Council.

Dr S. Buckland kindly provided a copy of the "Distance" program. Dr Alan Fielding, Dr Mike Hounsome and Dr Frank Lambert provided very useful discussions on analysis and/or census methods.

\section{References}

Andrew, P. (1992) The birds of Indonesia: a checklist (Peters' Sequence). Jakarta: Indonesian Ornithological Society.

Bibby, C. J., Burgess, N. D. and Hill, D. A. (1992) Bird census techniques. London: Academic Press.

Bollinger, E. K., Gavin, T. A. and McIntyre, D. C. (1988) Comparison of transects and circular plots for estimating bobolink densities. J. Wildl. Mgmt. 52: 777-786.

Buckland, S. T., Anderson, D. R., Burnham, K. P. and Laake, J. L. (1993) Distance sampling: estimating abundance of biological populations. London: Chapman and Hall.

Bühler, A. and Sutter, E. (1951) Reisebericht und allegemeine Einführung. Verh. Naturf. Ges. Basel 62: 181-217.

Büttikofer, J. (1892) On a collection of birds from the islands of Flores, Sumba and Rotti. Notes Leyden Mus. 14: 193-207. 
Capen, D. E., Fenwick, J. W., Inkley, D. B. and Boynton, A. C. (1986) Multivariate models of songbird habitat in New England forest. Pp. 171-175 in J. A. Verner, M. L. Morrison and C. J. Ralph, eds. Wildlife 20oo: modelling habitat relationships of terrestrial vertebrates. Madison: Wisconsin Press.

Dammerman, K. W. (1926a) Een tocht naar Soemba. Batavia (Jakarta): Ind. Com. Wetensch. Onderzoek.

Dammerman, K. W. (1926b) Flora en fauna van Soemba. Trop. Nat. 15: 73-82.

DeSante, D. F. (1986) A field test of the variable circular-plot censusing method in a Sierran subalpine forest habitat. Condor 88: 129-142.

FAO (1982) Feasibility studies of potential reserves of Sumba island. UNDP/FAOFO/INS/78/ 061 (Field rep. 43).

Forshaw, J. M. (1989) Parrots of the world. Third edition. Melbourne: Lansdowne Editions.

Fielding, A. H. (1993) A review of methods used to investigate bird-habitat associations. Report to Scottish Natural Heritage. Contract Number: NCCS/004/92/UPB.

Hartert, E. (1896) An account of the collections of birds made by Mr William Doherty in the Eastern Archipelago. Novit. Zool. 3: 148-183.

Hartert, E. (1898) Account of the birds collected in Sumba by Alfred Everett and his native hunters. Novit. Zool. 5: 466-476.

Haworth, P. F. and Fielding, A. H. (1988) Conservation and management implications of habitat selection in the merlin Falco columbarius L. in the South Pennines, U.K. Biol. Conserv. 46: 247-260.

ICBP (1992) Putting biodiversity on the map: priority areas for global conservation. Cambridge, U.K.: International Council of Bird Preservation.

Jones, M. J. and Banjaransari, H. (1990) The ecology and conservation of the birds of Sumba and Buru. Preliminary Report. PHPA/ICBP/Manchester Polytechnic.

Jones, M. J., Juhaeni, D., Banjaransari, H., Banham, W., Lace, L. A., Linsley, M. D. and Marsden, S. (1994) The ecology and conservation of the forest birds and butterflies of Sumba. Report to Indonesian Institute of Sciences (Bogor, Indonesia), Directorate of Forest Protection and Nature Conservation (Bogor, Indonesia) and BirdLife International (Cambridge, U.K.).

Juhaeni, D. (1993) Little-known oriental bird: the Sumba Hornbill Rhyticeros everetti. Bull. Oriental Bird Club: 18: 19-20.

Kendall, S. B. (1979) Citron-crested Cockatoos in Sumba. Avicult. Mag. 85: 93-94.

Laake, J. L., Buckland, S. T., Anderson, D. R. and Burnham, K. P. (1993) Distance user's guide. Fort Collins, U.S.A.: Colorado Cooperative Fish and Wildlife Research Unit, Colorado State University.

Lambert, F. (1993) Trade, status and management of three parrots in the North Moluccas, Indonesia: White Cockatoo Cacatua alba, Chattering Lory Lorius garrulus and Violeteared Lory Eos squamata. Bird Conserv. Internatn. 3: 145-168.

Mace, G., Collar, N., Cooke, J., Gaston, K., Ginsberg, J., Leader Williams, N., Maunder, M. and Milner-Gulland, E. J. (1992) The development of new criteria for listing species on the IUCN Red List. Species 19: 16-22.

Marsden, S. J. (1992) The distribution, abundance and habitat preferences of the Salmoncrested Cockatoo (Cacatua moluccensis) on Seram, Indonesia. Bird Conserv. Internatn. 2: 7-14.

Marsden, S. J. (in prep.) The nesting ecology of the parrots and hornbill of Sumba: some implications for species conservation.

Mayr, E. (1944) The birds of Timor and Sumba. Bull. Amer. Mus. Nat. Hist. 83: 123-194. McKnight, A., Jepson, P. and Raharjaningtrah, W. (in prep.) Figures of forest cover on Sumba. BirdLife International/PHPA Indonesia Programme report.

Meyer, A. B. (1882) Ueber Vögel von Einigen der Südöstlichen Inseln des Malayischen Archipels, Insbesondere uber diejenigen Sumba's. Verh. K. K. Zool-bot. Ges. Wein 31(9): 759-774. 
Meyer, A. B. (1892) The birds of Sumba. Notes Leyden Mus. 14: 265-268.

Rensch, B. (1931) Ueber einige Vogelsammlungen des Buitenzorger Museums von den Kleinen Sunda-Inseln. Treubia 13: 371-400.

Reynolds, R. T., Scott, J. M. and Nussbaum, R. A. (1980) A variable circular plot method for estimating bird numbers. Condor 82: 309-313.

Rowley, I. and Chapman, G. (1991) The breeding biology, food, social organisation, demography and conservation of the Major Mitchell or Pink Cockatoo Cacatua leadbeateri on the margin of the Western Australian wheatbelt. Aust. J. Zool. 39: 211-261.

Sibley, C. G. and Monroe, B. L. (1990) Distribution and taxonomy of birds of the world. New Haven: Yale University Press.

Sutter, E. (1955) Über die Mauser einiger Laufhühnchen und die Rassen von Turnix maculosa und sylvatica im indo-australischen Gebiet. Verh. Naturf. Ges. Basel. 66: 85139.

Torquebiau, E. F. (1986) Mosaic patterns in dipterocarp rain forest in Indonesia and their implications for practical forestry. J. Trop. Ecol. 2: 301-325.

Wiens, J. A., Rotenberry, J. T. and Van Horne, B. (1987) Habitat occupancy patterns of North American shrubsteppe birds: the effects of spatial scale. Oikos 48: 132-147.

White, C. M. N. and Bruce, M. D. (1986) The birds of Wallacea. London: British Ornithologists' Union (Checklist 7).

Zieren, M., Yus Rusila Noor, Baltzer M., and Najamuddin Saleh (1990) Wetlands of Sumba, East Nusa Tenggara: an assessment of values, developments and threats. Bogor, Indonesia: PHPA/AWB.

MARTIN J. JONES, MARK D. LINSLEY and STUART J. MARSDEN

Conservation Research Group, Dept of Biological Sciences, Manchester Metropolitan University, Chester Street, Manchester MI 5 GD, U.K. 